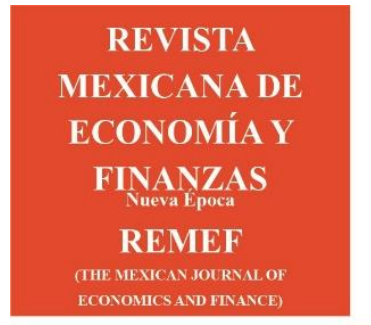

Revista Mexicana de Economía y Finanzas, Nueva Época

Volumen 15 Número 4, Octubre - Diciembre 2020, pp. 725-744

DOI: https://doi.org/10.21919/remef.v15i4.496

(Recibido: 14/mayo/2020, aceptado: 17/agosto/2020)

Special Issue: Energy \& Growth

Guest Editor: Ilhan Ozturk, Ph.D.

\title{
Causality and Stationarity with Structural Break in Electricity Consumption and GDP per capita in Mexico
}

\author{
Vicente German-Soto ${ }^{1}$ \\ Universidad Autónoma de Coahuila, México
}

\section{Abstract}

Electricity is the key in most production processes, therefore understanding causality, cointegration, and stationarity between electricity consumption and production is the starting point in the debate on its economic effects. Vector error correction model (VECM) and cointegration models, besides stationarity tests with structural break, were used to examine this relationship in Mexico over the period 1940-2018. Results support the hypothesis but only after to consider the structural change highlighted by the trade opening, since causality, stationarity, and cointegration can only be demonstrated by partitioning the period by 1985 , the production per capita breakpoint. In the first stage of the series, causality ran from electricity to product, while in the second stage it was bidirectional. It is recommended to adapt the electricity programs to changes in the political arena. The originality of this contribution lies in the long-term analysis of the energy sector, emphasizing the importance of the breakpoints. Despite of some sensitivity performing the regression analy sis, the conclusions recommend a strengthening of the energy sector as a feasible means of recovering the sustained growth achieved by Mexico in other times.

JEL Classification: Q43, C32, O54

Keywords: Energy consumption, income, causality, unit roots, structural break

\section{Causalidad y estacionariedad con cambio estructural en consumo de electricidad y PIB per cápita en México}

\section{Resumen}

La electricidad es clave en la mayoría de los procesos de producción, por tanto, entender causalidad, cointegración y estacionariedad entre consumo de electricidad y producción es un punto de partida en el debate de sus efectos económicos. Modelos de corrección de errores (VECM) y cointegración, junto a pruebas de estacionariedad, examinan esta relación en México durante 1940-2018. Los resultados apoyan esta hipótesis, pero después de considerar el cambio estructural subrayado por la apertura comercial, ya que causalidad, estacionariedad y cointegración solo pueden demostrarse dividiendo el periodo en 1985, fecha de quiebre estimada para producto per cápita. En la primera etapa, la causalidad corrió de electricidad a producto, mientras que en la segunda fue bidireccional. Se recomienda adaptar los programas de electricidad a cambios en la esfera política. La originalidad de esta contribución descansa en el análisis de largo plazo del sector de energía enfatizando la importancia de quiebres estructurales. A pesar de alguna sensibilidad al ejecutar las regresiones, las conclusiones recomiendan fortalecer el sector de energía como medio factible de recuperar el crecimiento sostenido que México alcanzó en otros tiempos.

Clasificación JEL: Q43, C32, O54

Palabras clave: Consumo de energía, ingresos, causalidad, raices unitarias, cambio estructural

\footnotetext{
${ }^{1}$ Unidad Camporredondo, Edificio “E”, entre Av. De los Maestros y David Berlanga, C.P. 25000, Saltillo, México. Telephone: +52844 41287 82, Fax: +528444102679.

E-mail: vicentegerman@uadec.edu.mx

ORCID ID: 0000-0001-5844-1296

* Sin fuente de financiamiento para el desarrollo de la investigación
} 


\section{Introduction}

Historical trends in the evolution of electricity consumption can be used to illustrate the economic development level reached by contemporary societies. In the case of Mexico, long-lasting improvements in income cannot be understood without understanding the role of the energy sector to that effect, especially the immense contribution of advances in electricity generation to industrial development.

For several decades, both income and electricity consumption experienced continuous increases, leading to a positive linear trend that broke down in the 1980s. Between 1940 and 1980 Mexico experienced high economic growth and high electricity consumption. The gross domestic product (GDP) per capita, which is considered a measure of average productivity, increased at an annual average rate of $6.06 \%$ in that period, more than even the $5.5 \%$ growth in population. Meanwhile, electricity consumption grew at an average annual rate of $64.9 \%$, while the average of the annual rates of Mexico's GDP, measured in absolute values, was $26.5 \%$.

However, since 1980 until 2018, the last year covered in this study, the GDP per capita growth has been extremely low. The average annual growth rate in that period was just $0.57 \%$, which was less than the average national population growth rate of $2.22 \%$ in the same period. Despite the increase in the average annual rate of electricity consumption at $6.33 \%$ and in the absolute GDP at $3.28 \%$, in comparison with the previous decades, the decline was huge. A comparison of the rates of growth of the first (1940-1980) and second periods (1980-2018) indicates a strong weakening of the tendency for long-term growth in the second period. The average annual rate of growth in electricity consumption was 10.2 times lower in the second period than in the first. This relative comparison was quite similar for GDP per capita, with the average growth over the second period around 10.6 times less than that of the first period, and this similarity says much about the high degree of association between both variables. Are these empirical regularities related? Does one lead to another? This study tries to give answers to these questions. Determining how they are associated is tantamount to evaluating the changes in economic growth vis-à-vis some programs and policies in the electric sector. The contribution of electricity to the gross domestic product in Mexico cannot be understood without considering the structural changes when studying this relationship from a historical perspective.

The strategy is to analyze the causality direction and the statistical properties of these variables, investigating if they changed over time and if they can also be considered as stationaries with trends that changed in specific moments, that is, stochastic analysis with structural breaks. Besides this analysis, tests on unit roots and cointegration have also been executed. To the author' knowledge, only few published studies have considered the possibility of breakpoints when performing time series analyses on issues related to the relationship between electricity consumption and production, despite the fact that the concept of breakpoints is an important factor that could bias conclusions about stationarity, causality, and cointegration.

Recently, the relationship between energy and income has become vital because it reflects the economic structure of an economy, a good understanding of which is necessary to achieve economic development (Abid and Mraihi, 2015, Srinivasan and Ravindra, 2015, Mighri and Ragoubi, 2020, Pegkas, 2020, Basu, Roy and Pal, 2020, among others). Moreover, energy consumption is an important component of the total expenditure in a country, so the government seeks ways to reduce this burden and to improve the well-being of the people. Also, energy is a steadily increasing input in the production processes of all economies. For example, in the U.S. more than half of the observed increase in output per worker is 
attributed to energy efficiency (Howarth, 1997), therefore governments are making considerable effort to improve their energy sectors which in turn boost economic growth. To reach these objectives, there is the need for more studies on which energy policies can be based.

Results, in advancing, are in the direction of the growth hypothesis, that is, causality goes from electricity consumption to production, but this relationship shows a changing equilibrium in the long run and, for the second period estimated in this work, it became bidirectional. The sustained link after the broken trend suggests that Mexico's economic growth is highly dependent on the country's electricity consumption, an important factor that affects income and so economic growth. If Mexico desires to recover its past sustained economic growth, it should review its programs and policies on energy investment.

With this introduction as the first section of this paper, the second section offers a review of the stationarity of energy consumption and income around the world. In the third section, data is explained, and the methodological strategy is developed in the fourth section. Finally, empirical results are analyzed and concluding comments made in the fifth and sixth sections respectively.

\section{A brief review of the stationarity of energy consumption and GDP}

The stationarity of the energy consumption and GDP per capita has recently received much attention. Most studies on the subject argue that the idea of long run dynamics is very useful for testing several hypotheses related to economic growth. One such hypothesis is the conservation hypothesis, which arises whenever an energy policy has a small or no effect on economic growth. The opposite case, known as the growth hypothesis, arises when the effects on economic growth are significant. Other studies have found empirical evidence for the neutrality hypothesis regarding the relationship between energy and economic growth in the short run, but also for the long run in some cases. Depending on if the effects are temporary or permanent, it will be possible to infer the economic growth from the energy sector. Consequently, with the knowledge on the statistical properties of the variables, the government could make use of more efficient instruments to reduce, for example, harmful emissions without any effect on economic growth. Despite that the nexus between energy and income could be considered as an empirical regularity, the evidence remains inconclusive. Ozturk (2010) reviewed the literature on this nexus and concluded that more studies with new approaches and perspectives are necessary in order to establish this connection. In particular, studies on electricity consumption constitute a very important step towards the creation of energy policies. Bertoldi and Atanasiu (2011) carried out a survey on trends in energy policy creation in the European Union and found that studies on electricity consumption have been under-represented. This implies that more studies on electricity consumption trends need to be conducted.

Different studies on the link between energy consumption and income per capita have been conducted using different methodologies for various countries. The most popular methods of time series analysis are unit roots tests, cointegration analysis, and causality. Lee (2005) analyzed this link using panel unit root and estimated the causality for 18 developing countries from the period 1975 to 2001 . He found causalities from energy consumption to GDP, but not vice versa. Miketa and Mulder (2005) studied the energy-productivity convergence across 56 countries for the period 1971-1995 and found much persistence in cross-country differences. Gross (2012) found that the neutrality hypothesis is supported on the aggregate and disaggregate level in the short run and unidirectional causality goes from energy to value added in the U.S. For Turkey, Abid (2016) found mixed results for causality and evidence on the neutrality hypothesis, 
while Bayraktutan, Arslan, Öskan and Çevik (2012) suggest that Turkey must increase energy supplies to improve the conditions of energy use, due to the positive relationship of energy with economic growth.

Omay, Hasanov and Uçar (2014) discussed the nonlinear aspects for the G7 countries. The results revealed a long run relationship between energy consumption and output level in a process where the adjustment to the equilibrium is nonlinear.

Srinivasan and Ravindra (2015) also found a long run relationship in India. They estimated the causal nexus between energy consumption and economic growth and confirmed that the second variable is driven by the first. Abid and Mraihi (2015) analyzed the relationship between industrial production and energy consumption in Tunisia for the period 1980-2007. The study highlighted that if Tunisia reduced its dependence on fossil fuels, it could boost its national development. Abid (2016) estimated the causality while considering the informal sector in Tunisia and found that this was mixed, but the results supported the neutrality hypothesis in the short run. However, Mighri and Ragoubi (2020), also on Tunisia, found empirical support for the conservation hypothesis in the long run, but the growth hypothesis dominates in the short run.

Using Granger causality tests, Saidi, Mbarek and Amamri (2018) estimated a bidirectional relationship for the MENA countries between 1990 and 2012. ${ }^{2}$ Similar conclusion was reached in the study on the U.S. by Arora and Shi (2016), who used Granger causality tests to demonstrate the bidirectional relationship in the 1990s, but a "GDP to energy consumption" unidirectional relationship in the 2000s. For a set of sub-Saharan African countries, Zerbo (2017) executed Granger causality tests to find a long run relationship between energy consumption and economic growth in 8 out of 13 countries. Some countries were more identified with the growth hypothesis, while others observed the conservation hypothesis.

In a sample of 91 countries, Kablamaci (2017) highlighted the existence of mixed results based on the concept of Granger causality. In one group of countries causality was unidirectional, running from energy to economic growth; a second group validated the conservation hypothesis, but for a third group there was no causal relationship.

Shahbaz, Tiwari and Khan (2016) indicated that energy consumption follows a stationary process in high- and middle-income countries, but it has a unit root process in low-income countries, possibly due to the lack of policies with long run effects.

Ozcan and Ozturk (2019) demonstrated the existence of the neutrality hypothesis in 16 emerging economies when analyzing the relationship between renewable energy consumption and economic growth. As a result, policies directed at energy saving almost have no influence on the growth rates in these emerging economies.

Different studies on the stationarity property of energy consumption have yielded different results because empirical results change with both the disaggregation sectoral level and the panel level. For instance, Erdogan, Akalin and Oypan (2020) investigated if energy consumption shocks are transitory or permanent in Turkey. Unit root tests indicate that energy use is non-stationary but changes when it is disaggregated by a sector and if it uses panel data. Minh and Ngoc (2020) reported bidirectional causality between energy consumption and economic growth in Vietnam over the period 1971-2017. However, the effects were asymmetric because the negative changes produced greater effects than the positive changes.

\footnotetext{
${ }^{2}$ The following are typically known as the MENA countries: Algeria, Bahrain, Djibouti, Egypt, Iran, Iraq, Israel, Jordan, Kuwait, Lebanon, Libya, Malta, Morocco, Oman, Qatar, Saudi Arabia, Syria, Tunisia, United Arab Emirates, Palestine, and Yemen.
} 
Moutinho, Madaleno and Bento (2020) studied the causality and cointegration among economic growth, energy consumption, and $\mathrm{CO}_{2}$ emissions of six sectors in Portugal and Spain. Using error correction models, they confirmed results in both directions among the variables and an inverted U-shaped relationship only in one sector. Differently, Joshua, Uzuner and Bekun (2020) confirmed causality runs from pollutant emissions to economic growth in Nigeria, and this is so because dirty energy sources are more common in developing countries where non-renewables energies are more expensive. A similar set of variables have also been investigated for West Africa by Musah, Kong, Mensah, Antwi and Donkor (2020), who concluded that economic growth has seen no influence.

Some studies on Mexico have highlighted a positive relationship between energy consumption and GDP per capita. Chang and Martinez-Chombo (2003) estimated an electricity demand function for Mexico and found an inelastic demand with respect to changes in income in the period 1985-2000. This result suggests that income and electricity prices followed different paths in the long run. Dieck-Assad and Peralta (2013) found an explanation for the asymmetric economic growth experienced by Mexico before and after 1980, attributing the slowdown in economic growth that occurred after 1980 to increments in energy prices, which negatively impacted the productivity. In studies focused on issues related to the causality problem, Narayan and Prasad (2008), applying Granger causality tests on 30 OECD countries including Mexico, gave evidence of the absence of a causal relationship in Mexico's case, concluding therefore that, differently to most OECD countries, electricity conversation policies will not affect its real GDP. Gómez and Rodríguez (2015) found stationarity with two structural changes and causality relationship running from GDP per capita to electricity consumption between 1971 and 2011. Massa and Rosellón (2020) found no evidence of causal relation in a Granger sense between electricity production and Mexico's GDP for the period 1965-2018, although the long run relationship can be affected by structural changes not considered, which may bias the Granger causality tests. Islas-Samperio, Birlain-Escalante and Grande-Acosta (2020) studied scenarios of low-carbon use in Mexico's industrial sector, and their results indicate that measures directed at reducing the use of carbon fuel mitigate the emission of pollutants, but the main challenge to the use of low-carbon energy sources is finding funding sources.

\section{Data and exploratory analysis}

The data consists of four main series collected for each year between 1940 and 2018, viz.: electricity consumption (EC) in gigawatts/hour, gross domestic product (GDP) in levels, GDP per capita, and the GDP-electricity consumption (GDP/EC) ratio. The sources of the data are the Instituto Nacional de Estadística y Geografía (INEGI, 2008) for the national GDPs, the Ministry of Energy for electricity consumption, and the Consejo Nacional de Población (CONAPO) for population. All variables are considered as logarithms.

Figures 1, 2, and 3 describe the historical levels of the electricity consumption, GDP per capita, and GDP/EC ratio. They all show increasing trends with time until the 1980s, as expected, and from then a break in the trend is observed. Specifically, the slopes for the GDP per capita and the GDP/EC ratio become almost horizontal in the second period, defined by the break in the 1980s. 


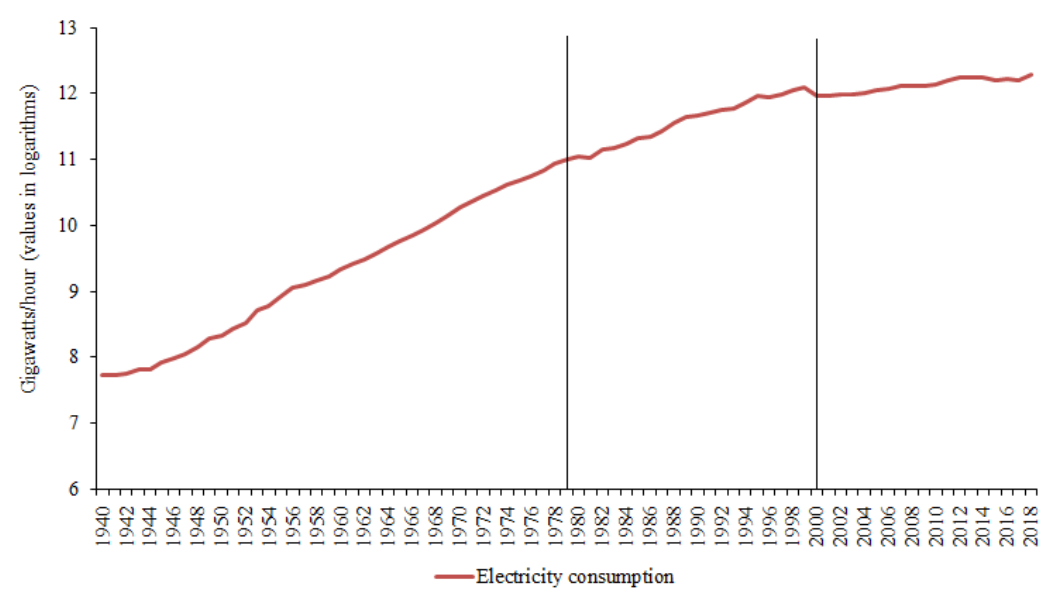

Figure 1. Levels of electricity consumption, 1940-2018.

Source: author's own elaboration.

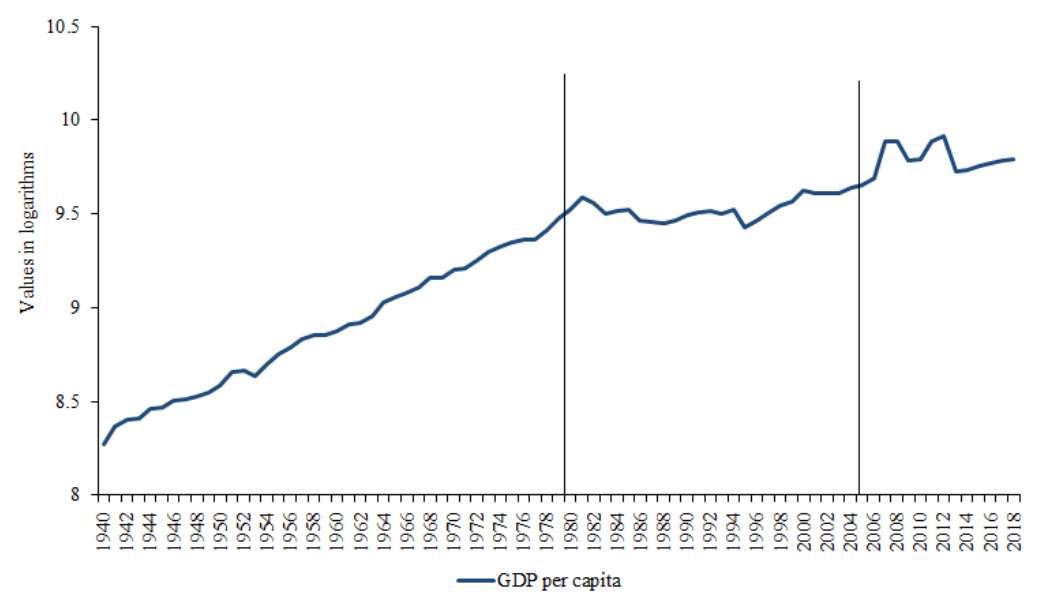

Figure 2. Levels of GDP per capita, 1940-2018. Source: author's own elaboration.



Figure 3. Historical trend of the GDP/Electricity consumption ratio, 1940-2018. Source: author's own elaboration. 
Vertical bars in Figures 1, 2, and 3 indicate that variables could be defined by one or two breaks in their trends. Both breakpoints seem to occur at quite similar moments, around 1980 for the first and 20002005 for the second.

However, for electricity consumption, the possibility of only one break is clearer than that of two, as seems to be the case for the other variables. Figure 4 suggests that until the 1980s, electricity consumption and GDP per capita had relatively stable trajectories in the which they were continuously on the increase. Despite the fact that the slopes of both series have been weakening since the eighties, the series follow different paths from then on.

Electricity consumption exhibited a flatter conduct but still kept an ascendant trajectory, while GDP per capita became completely flat between 1980 and 1995. After 1995, GDP per capita seemed to recover its positive slope, but it has remained unstable, indicating that its equilibrium level has not yet been reached. It is possible that both series changed to a different equilibrium path after the 1980s due to changing conditions in the economy. In that case, their old equilibrium level will be unattainable if the new economic conditions at least persist. One way to find out is by investigating if they can be stationary with broken trends.

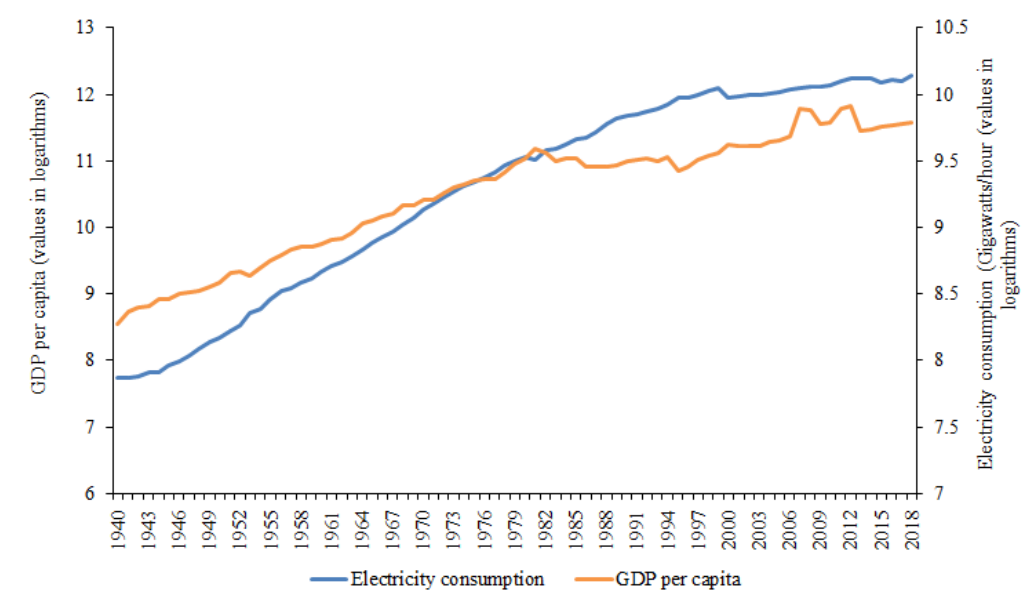

Figure 4. Historical trends in electricity consumption and GDP per capita, 1940-2018.

Source: author's own elaboration.

In whichever case, the exploratory analysis indicates that electricity consumption and GDP per capita experienced a very different situation from the past behavior. Due to the slowdown of the Mexican economy since the eighties, it is necessary to investigate the role of electricity consumption on this new path of economic growth. For example, how important will the structural changes exhibited by the Mexican economy be? How significant has the gap between electricity consumption and income been since the 1980s?

To sum up, the descriptive analysis shows that GDP, and therefore GDP per capita, is associated with electricity consumption. However, this evidence does not stablish causality and cointegration from which we can infer the growth hypothesis in Mexico. 


\section{Methods of data analysis}

In time series analysis, three kinds of tests are executed. First, depending on the causality direction between electricity consumption and GDP per capita, it is possible to implement one or another economic policy. For example, if electricity consumption affects GDP per capita, then the growth hypothesis dominates and policies that promote the generation of electricity positively benefit economic growth. However, as the literature review suggests, there is yet no consensus on the causality relationship between electricity consumption and the different measures of income. Causality may run in either direction, and if it goes from electricity consumption to income per capita, then there exists an energy-dependent economy and electricity positively affects income generation, but if the reverse is the case, that is causality goes from income per capita to electricity consumption, then only a few of the effects of policies that promote electricity generation will be felt by income.

The estimation of vector error correction models (VECM) follows the next set of equations:

$$
\Delta Y_{t}=\alpha E C T_{t-1}+\Gamma_{1} \Delta Y_{t-1}+\Gamma_{2} \Delta Y_{t-2}+\ldots+\Gamma_{p} \Delta Y_{t-p}+\varepsilon_{i}
$$

where $\mathbf{Y}$ is a matrix of variables, the $\Gamma$ 's are matrices of short run parameters, $\alpha$ represents a matrix of parameters in a dynamic of adjustment towards the equilibrium, and ECT is a matrix representing the mechanism of error correction. One requirement for the VECM is the stationarity of the series. This study uses the log likelihood, the Akaike, and the Schwarz (BIC) criteria for determining the optimal lag.

The definition of the integration order of the variables is carried out by applying unit root tests. This second approach is conducted in two phases. Firstly, unit root tests are applied on the level of the series. If the series are integrated, but their first differences are stationary, then it means that the series are integrated to the order 1 . However, despite that the two series are not stationary, it is still possible that they can be cointegrated. With this end in view, we execute the Johansen and Engle-Granger cointegration tests. To test for the rank of cointegration, Johansen's likelihood ratio (LR) test using both trace and maximum statistics will be employed, while for the Engle-Granger test, the evidence rests on the $\tau$ and $z$ statistics.

In brief, the methodological strategy for these last two approaches is as follows. We apply the modified tests of $\mathrm{Ng}$ and Perron (2001) following the next stochastic process:

$$
x_{t}=d+\rho x_{t-1}+\sum_{j=1}^{k} \hat{\beta}_{j} \Delta x_{t-j}+e_{t k}
$$

where $x_{t}$ is the variable of interest and $d$ represents the data generator process (DGP), which for example can indicate if a series evolves into a constant or linear trend, or into both. The sum of $k$ terms to the right of the equation are introduced to control for serial correlation and the coefficient $\rho$ tests for stationarity. $\mathrm{Ng}$ and Perron (2001) derived four modified unit root tests (known as $M$ tests). In the definition of the lag order for the autoregressive correction, they suggest selecting $k$ such that $k_{\text {maic }}=$ $\operatorname{argmin}_{k} \operatorname{MAIC}(k)$.

Because some tests perform better than others in the presence of heteroskedasticity and autocorrelation, this exercise considers tests based on both parametric and non-parametric estimation. The evidence is complemented with tests defining the null hypothesis of stationary series as opposed to others 
that define the null of unit roots in the series. This study rests on seven tests of unit roots: $Z_{\alpha}, M Z_{\alpha}, M Z_{t}$, $\mathrm{ADF}^{\mathrm{GLS}}, \mathrm{MSB}, \mathrm{P}_{\mathrm{T}}$, and $\mathrm{MP}_{\mathrm{T}}$. These specifications and their technical details can be found in $\mathrm{Ng}$ and Perron (2001).

If the series are not stationary and cointegrated, one reason may be the presence of structural breaks that introduce noise when estimating the stationarity. Therefore, a third data analysis approach in this study is the estimation of stationarity tests while taking into account structural breaks. As our sample period witnessed several crises, such as the 1995 Mexican "Tequila" and the 2007-2009 global Great Recession, and the change exhibited by the Mexican economy towards an open production model in the eighties, we apply the Zivot and Andrews (1992) and Lumsdaine and Papell (1997) stationarity tests which make it possible to consider the two structural breaks. Using a general equation, the strategy followed for these authors is given by:

$$
x_{t}=\mu+\beta t+\theta_{1} D U 1_{t}+\gamma_{1} D T^{*} 1_{t}+\theta_{2} D U 2_{t}++\gamma_{2} D T^{*} 2_{t}+\alpha x_{t-1}+\sum_{i=1}^{k} c_{i} \Delta x_{t-i}+\varepsilon_{t}
$$

where $x_{t}$ is the variable of interest, DU1 and DU2 are dummy variables for mean shift occurring at times TB1 and TB2 respectively, and $\mathrm{DT}^{*} 1$ and $\mathrm{DT}^{*} 2$ are the corresponding trend shift variables (see Lumsdaine and Papell, 1997). The parameter that determines the stationarity of the variable is $\alpha$. Equation (3) contains several decisions about the DGP of the time series. If the time series selects the complete model in (3), then the variable contains two structural breaks with a constant and linear trend (model CC of Lumsdaine and Papell, 1997), which is our preferred selection because the series are dominated by changes in both constant and trend. Essays with different specifications did not improve the results of the model CC. In addition, the locations of the breakpoints are unknown; this means that the program endogenously determines the date with a better adjustment.

The empirical strategy to demonstrate causality and cointegration with time series analysis is quite simple. If unit root tests applied on the levels of the series determine that the series are non-stationary, then causality tests can be biased but it is still possible that the series are cointegrated. So, we conduct the cointegration tests of Engle-Granger and Johansen. If we can still stablish no cointegration, then we investigate the presence of structural changes. Once the breakpoints have been located, we re-estimate the causality and cointegration tests, dividing the series around the estimated structural breaks. Once the stationarity of the series with structural breaks is defined, then it will be possible to conclude and suggest suitable recommendations for public policies.

\section{Results and analysis}

A first approximation in the time series approach is the investigation of the order of integration of the series. For this, we apply the aforementioned tests of stationarity. Estimates are reported in Table 1, where it can be seen that GDP, GDP per capita, and electricity consumption are non-stationary in levels, but stationary in first differences. Thus, each of these variables can be denoted as I(1) and the differences as I(0). While Table 1 shows the results for both possibilities of evolution of the series, i.e. constant-only trend and constant and linear trend, our preferred definition of unit root is the second due to the increasing tendency that characterize the variables.

There is a consensus that every variable has at least one unit root. All the tests conclude that variables in levels accept the null hypothesis of unit root (for the first four tests in Table 1) and reject the 
null hypothesis of stationarity (for the last three tests in Table 1). This direction of result is confirmed when tests are executed in first differences. In this second case, conclusions are inverted. Now, most tests consider that variables are stationaries in first differences, although some disparities still prevail among them, mainly regarding electricity consumption. However, it is known that tests of unit roots can fail when the presence of structural breaks is not attended to in the estimates. This last case can also be studied by assessing the relationship between the variables in the short and long run. Accordingly, the Johansen and Engle-Granger tests of co-integration for GDP and GDP per capita with electricity consumption have been checked (Table 2). In testing for the rank of cointegration, we have employed Johansen's likelihood ratio test using both trace and maximum statistics. In all the bivariate settings, the variables are not cointegrated. Consensus between Johansen's test and Engle-Granger test leads to the conclusion that no cointegration exists. The causality relationship between these estimates is in doubt because the acceptation of the null implies the existence of no causality in any direction.

Table 1. Standard unit root tests on variables in levels and first differences

\begin{tabular}{|c|c|c|c|c|c|c|c|c|}
\hline & EC & GDP & GDPpc & GDP/EC & EC & GDP & GDPpc & GDP/EC \\
\hline & \multicolumn{4}{|c|}{ Only constant } & \multicolumn{4}{|c|}{ Constant and linear trend } \\
\hline & \multicolumn{8}{|c|}{ Variables in levels } \\
\hline$k$ & 4 & 4 & 0 & 1 & 2 & 0 & 0 & 0 \\
\hline$Z \alpha$ & -3.911 & 0.473 & 0.788 & 0.502 & -1.366 & -0.608 & -3.388 & -0.493 \\
\hline$M Z \alpha$ & -3.711 & 0.688 & 1.008 & 0.685 & -1.249 & -0.345 & -3.020 & -0.423 \\
\hline$M Z_{t}$ & -1.185 & 0.602 & 1.571 & 0.983 & -0.505 & -0.173 & -1.036 & -0.218 \\
\hline$A D F^{G L S}$ & -0.415 & 0.632 & 1.228 & 0.633 & -0.555 & -0.305 & -1.163 & -0.254 \\
\hline$M S B$ & $0.319 *$ & $0.875 *$ & $1.559 *$ & $1.433 *$ & $0.404 *$ & $0.503 *$ & $0.343 *$ & $0.515 *$ \\
\hline$P_{T}$ & $9.358 *$ & $73.527 *$ & $\begin{array}{c}231.563 \\
*\end{array}$ & $\begin{array}{c}177.581 \\
*\end{array}$ & $39.606 *$ & $64.662 *$ & $29.327 *$ & $60.201 *$ \\
\hline \multirow[t]{2}{*}{$\overline{M P_{T}}$} & $6.676^{*}$ & $51.744 *$ & $\begin{array}{c}159.906 \\
*\end{array}$ & $\begin{array}{c}127.100 \\
*\end{array}$ & $38.322 *$ & $57.859 *$ & $25.602 *$ & $59.447 *$ \\
\hline & \multicolumn{8}{|c|}{ Variables in first differences } \\
\hline$k$ & 3 & 3 & 1 & 0 & 2 & 0 & 1 & 0 \\
\hline$Z \alpha$ & $\begin{array}{c}-10.253 \\
*\end{array}$ & $-23.799 *$ & $-92.071 *$ & $-64.993 *$ & $-18.922 *$ & $-62.134 *$ & $-102.401 *$ & $-66.683 *$ \\
\hline$M Z \alpha$ & -3.104 & -6.037 & $-60.772 *$ & $-37.891 *$ & -8.074 & $-37.228 *$ & $-67.968 *$ & $-38.129 *$ \\
\hline$M Z_{t}$ & -1.153 & -1.737 & $-5.512 *$ & $-4.334 *$ & -1.988 & $-4.312 *$ & $-5.829^{*}$ & $-4.355 *$ \\
\hline$A D F^{G L S}$ & -1.472 & $-2.406 *$ & $-7.655 *$ & $-7.434 *$ & -2.305 & $-7.197 *$ & $-8.216^{*}$ & $-7.616^{*}$ \\
\hline$M S B$ & $0.371 *$ & $0.287 *$ & 0.0907 & 0.114 & $0.246 *$ & 0.115 & 0.085 & 0.114 \\
\hline$P_{T}$ & 9.664 & 4.548 & 0.409 & 0.728 & $13.156 *$ & 2.672 & 1.352 & 2.477 \\
\hline$M P_{T}$ & 7.751 & 4.059 & 0.403 & 0.699 & $11.346 *$ & 2.459 & 1.341 & 2.450 \\
\hline
\end{tabular}

Notes: the number of lags (k) is optimally selected according to the modified information criterion (MAIC) by Ng and Perron (2001) with $\mathrm{k}_{\max }=5$ lags. Critical values in the case of constant-only trend are (5\%): $\mathrm{Z} \square$ and MZ $\square$ (-8.1), MZt and ADF (-1.98), MSB (0.233), $\mathrm{P}_{T}$ and MP $\mathrm{MP}_{T}$ (3.17). For the constant and linear trend, the critical values are (5\%): $\mathrm{Z} \square \mathrm{MZ} \square$ (-17.3), MZt and ADF (-2.91), MSB (0.168), PT and MPT (5.48). The null hypothesis for $\mathrm{Z} \square, \mathrm{MZ} \square, \mathrm{MZt}$, and ADF is that the series has a unit root, while MSB, $\mathrm{P}_{T}$, and MPT define the null of stationarity. The superscript * indicates significance at $5 \%$.

Source: author's own estimates. 
The direction of causality is crucial because in this case it determines the ideal energy policy. If causality goes from electricity consumption to income, then it is possible that the design of policies impacts income and economic growth, but if causality is from income to electricity consumption, then whichever policy will have little or no effect on economic growth (Asafu-Adjave, 2000 and Kablamaci, 2017). For this reason, we have also carried out causality tests using the VECM approach. Because the VECM estimates require appropriate lag length selection, we have first conducted a vector autoregressive (VAR) model to select the value of lag based on the log likelihood, Akaike, and Schwarz criteria, and then estimate the VECM using the selected lag length.

Table 2. Results of cointegration tests (overall period)

\begin{tabular}{|c|c|c|c|c|}
\hline \multicolumn{5}{|c|}{ Engle-Granger cointegration results } \\
\hline Dependent & $\tau$-statistic & p-value & z-statistic & $\begin{array}{c}\text { p- } \\
\text { value }\end{array}$ \\
\hline & \multicolumn{4}{|c|}{ Series: GDP, Electricity consumption } \\
\hline GDP & -2.990 & 0.290 & -14.310 & 0.358 \\
\hline \multirow[t]{2}{*}{ Electricity consumption } & -2.521 & 0.522 & -11.491 & 0.531 \\
\hline & \multicolumn{4}{|c|}{ Series: GDP per capita, Electricity consumption } \\
\hline GDP per capita & -3.036 & 0.271 & -14.916 & 0.326 \\
\hline Electricity consumption & -1.984 & 0.785 & -8.219 & 0.754 \\
\hline \multicolumn{5}{|c|}{ Johansen cointegration results } \\
\hline & Eigenvalue & $\begin{array}{c}\text { Trace } \\
\text { statistic }\end{array}$ & Critical Value & $\begin{array}{c}\text { p- } \\
\text { value }\end{array}$ \\
\hline & \multicolumn{4}{|c|}{ Series: GDP, Electricity consumption } \\
\hline None & 0.215 & 23.181 & 25.872 & 0.104 \\
\hline \multirow[t]{2}{*}{ At most 1} & 0.061 & 4.787 & 12.518 & 0.627 \\
\hline & \multicolumn{4}{|c|}{ Series: GDP per capita, Electricity consumption } \\
\hline None & 0.205 & 22.495 & 25.872 & 0.124 \\
\hline At most 1 & 0.064 & 5.035 & 12.518 & 0.591 \\
\hline
\end{tabular}

Source: author's own estimates.

In the cointegration equation, the coefficients of GDP and GDPpc are normalized to one. The alternative of normalizing the coefficient of electricity consumption have yielded similar estimates. According to the results in Table 3, both income variables exhibit positive long run relationships with electricity consumption, but none of these relationships is significant. The $\ln (\mathrm{GDP})$ equation estimates a yearly adjustment of about $-13.7 \%$ to disequilibrium in the long run relationship. The negative value implies that the variations in the GDP are above its equilibrium value, and they need to be reduced in order to correct the disequilibrium. This process is quite similar for the GDP per capita equation, although in this case the adjustment is lightly superior, around $16.6 \%$. The $\ln (\mathrm{EC})$ equation, on the other hand, corrects about $9.3 \%$ and $9.7 \%$ of disequilibrium in GDP and GDPpc, respectively, in a year. For the GDP equation, the VECM have statistically significant adjustment parameters, but their significance is weak (it is only 
significant at 10\%) in the $\ln (\mathrm{EC})$ equation; for the GDPpc equation, the adjustment parameter for $\ln (\mathrm{EC})$ equation is not significant, so the long run causality runs only in one direction: from level of electricity consumption to income level.

Table 3. Estimation results of the bivariate VECM (overall period)

\begin{tabular}{|c|c|c|}
\hline \multicolumn{3}{|c|}{ Equation of GDP and electricity consumption (EC) } \\
\hline & \multicolumn{2}{|c|}{ Dependent variable } \\
\hline Regressors & $\Delta \ln ($ GDP $)$ & $\Delta \ln (\mathrm{EC})$ \\
\hline $\mathrm{ECT}_{\mathrm{t}-1}$ & $-0.137 * *(-2.282)$ & $0.093 *(1.754)$ \\
\hline$\Delta \ln (\mathrm{GDP})_{\mathrm{t}-1}$ & 0.149 (1.282) & $-0.006 \quad(-0.057)$ \\
\hline$\Delta \ln (\mathrm{EC})_{\mathrm{t}-1}$ & $0.121(0.958)$ & $0.114(1.021)$ \\
\hline Constant & $0.045 * * \quad(2.325)$ & $0.095 * * * \quad(5.554)$ \\
\hline \multicolumn{3}{|c|}{$\begin{array}{c}E C T=\ln (G D P)-0.447 \ln (E C) \\
(-4.927)\end{array}$} \\
\hline \multicolumn{3}{|c|}{$\begin{array}{l}\text { Equation of GDP per capita (GDPpc) and electricity consumption } \\
\text { (EC) }\end{array}$} \\
\hline Regressors & $\Delta \ln ($ GDPpc $)$ & $\Delta \ln (\mathbf{E C})$ \\
\hline $\mathrm{ECT}_{\mathrm{t}-1}$ & $-0.166 * *(-2.561)$ & $0.097 \quad(1.652)$ \\
\hline$\Delta \ln (\mathrm{GDPpc})_{\mathrm{t}-1}$ & $0.115 \quad(0.986)$ & $-0.013 \quad(-0.124)$ \\
\hline$\Delta \ln (\mathrm{EC})_{\mathrm{t}-1}$ & $0.100 \quad(0.797)$ & $0.102(0.895)$ \\
\hline Constant & $0.018 \quad(1.041)$ & $0.096 * * * \quad(5.982)$ \\
\hline \multicolumn{3}{|c|}{$\begin{array}{c}E C T=\ln (G D P p c)-0.211 \ln (E C) \\
(-2.663)\end{array}$} \\
\hline
\end{tabular}

Notes: Numbers in parentheses are t-statistics. The superscripts $* * *, * *$, and $*$ indicate significance at $1 \%, 5 \%$, and $10 \%$, respectively. Estimates based on an optimal lag $=1$, according to the Schwarz criterion (BIC).

Source: author's own estimates.

There is unidirectional causality in the short run. It means that the economic activities in Mexico depend on energy use to grow. The policy implications are obvious. If Mexico is an electricity importer, it should be ready to face the volatility in the market of electricity prices, while if Mexico is an exporter, or self-sufficient, it should enable a productive structure that allows it to obtain the maximum possible profits.

In the VECM estimates, however, the short run changes in electricity consumption, although positive, have no significant effect on the income variables. Our thesis is that the estimates may have been affected by structural changes that have not been considered. If this is so, then estimates of the parameters can be biased. Thus, the purpose is to test, taking into account the possibility of such structural changes, and locate the dates of the breaks. If, considering breakpoints, the series are stationary, then it is possible to examine the equilibrium relationship in each period identified by the breakpoints. The GDP/EC ratio will inform the equilibrium relationship because it assesses how the gap between these two variables evolves before and after the breaks. 
Tests with up to two structural breaks are reported in Table 4. Visual inspection of macroeconomic variables indicates that the presence of structural changes affects the time series, so structural breaks should be considered. Results in Table 4 agree that the all series are stationary with at least two endogenously determined breakpoints. One advantage is that estimated time breaks are not imposed but they are endogenously identified when running the programmed routines to estimate the equation (3). This way, causality estimates are not dependent on the external condition.

Both structural breakpoints seem to be more related to the real macroeconomic events. For example, both income variables select time-breaks in the eighties. GDP selects 1982 (the economy began to open from 1982-1986, during which time some crises took place) and 2008 (a date widely related to the global economic crisis), while GDP per capita selects 1985 and 2008. Electricity consumption, for a change, selects breakpoints more linked to economic crises (the devaluation of the Mexican Peso in 1976 and 2000; between 2000 and 2003 Mexico experienced stagnation provoked by the recession in the U.S.). Finally, the GDP/electricity consumption ratio selects 1973 (the international oil crisis) and 1995 (the Mexican crisis, known as the 'tequila crisis').

We can arrive at some interesting conclusions by investigating the estimated coefficients, taking advantage of the fact that the series are stationary. For example, after the second structural break, all the variables exhibit not only a negative trend from then on but also a fall in levels because the dummy measuring the change in the intercept $\left(\theta_{2}\right)$ is negative. This is an important finding because it reveals that the slowdown experienced by the Mexican economy can be explained by the reduction in one basic production input, i.e. electricity, which also affects economic growth. While the positive sign estimated for the first breakpoint $\left(\gamma_{1}\right)$ partially corrects the fall in the income level (also in the level of electricity consumption) as a consequence of the slowdown (see the coefficient of $\theta_{1}$ ), in the stage defined by the second structural break the slowdown is reinforced since both the intercept and slope are now negative and highly significant (see the estimates for $\theta_{2}$ and $\gamma_{2}$ ).

Table 4. Unit roots tests with two structural breaks in both intercept and slope

\begin{tabular}{|c|c|c|c|c|}
\hline & EC & GDP & GDP per capita & GDP/EC ratio \\
\hline TB1/TB2 & $1977 / 2000$ & $1981 / 2008$ & $1985 / 2008$ & $1973 / 1995$ \\
\hline$\mu$ & 3.249 & 14.608 & 7.185 & 0.791 \\
\hline & $(6.261)$ & $(8.032)$ & $(8.075)$ & $(6.342)$ \\
\hline$\beta$ & 0.039 & 0.077 & 0.025 & 0.004 \\
\hline & $(6.253)$ & $(8.002)$ & $(7.908)$ & $(5.965)$ \\
\hline$\theta 1$ & -0.008 & 0.111 & -0.143 & 0.001 \\
\hline & $(-0.481)$ & $(4.098)$ & $(-6.381)$ & $(0.379)$ \\
\hline$\gamma 1$ & -0.118 & 0.202 & 0.192 & 0.012 \\
\hline$\theta 2$ & $(-5.471)$ & $(6.654)$ & $(5.864)$ & $(3.546)$ \\
\hline & -0.015 & -0.046 & -0.017 & -0.001 \\
\hline$\gamma 2$ & $(-6.306)$ & $(-8.026)$ & $(-6.445)$ & $(-4.532)$ \\
\hline & -0.015 & -0.012 & -0.016 & -0.003 \\
\hline
\end{tabular}




\begin{tabular}{|c|c|c|c|c|}
\hline $\boldsymbol{\alpha}$ & $\mathbf{- 0 . 4 2 8 c}$ & $\mathbf{- 0 . 2 6 6 ~ a}$ & $\mathbf{- 0 . 8 6 2} \mathbf{~ a}$ & $\mathbf{- 0 . 1 3 6 ~ b}$ \\
\hline$k$ & $(-6.131)$ & $(-7.974)$ & $(-8.039)$ & $(-6.081)$ \\
\hline$k$ & 0 & 7 & 1 & 10 \\
\hline \multicolumn{2}{l}{ Notes: TB1 and TB2 are estimated dates of structural breaks. $t$ values are in parentheses. Critical values: } \\
\hline $\begin{array}{l}-7.34(1 \%),-6.82(5 \%), \text { and }-6.49(10 \%) \text {. Superscripts a, b, and c stand for rejection of the null hypothesis } \\
\text { of unit root at the 1, 5, and 10\% levels of significance, respectively. }\end{array}$
\end{tabular}

Source: author's own estimates.

Empirical results indicate that electricity consumption follows a stationary process only after the presence of structural breaks has been taken into account. This has at least two implications. First, despite that the use of electricity has changed over time, the equilibrium path is recovered once the effects of the adverse events disappear. Second, the short-run energy policies should be made in such a way that they sustain the income per capita level and fulfill the energy demand of Mexico. This is also a recommendation used in some high- and middle-income countries (Shahbaz, Tiwari and Khan, 2016).

In the case of the Mexican electricity industry, we can clearly affirm that the transition from a public monopoly (first stage) to an open market (second and most recent stage) implied significant risks. Some authors, such as Rodríguez (2016), consider that the main problem of Mexico in the open market lies in the State's intervention, that is, public monopoly was done away with, yet State interventionism has continued to prevail, and this discourages private sector investments now that more alternatives to generate electricity exist.

The most linked breakpoint in the changes that occurred in the economic sphere agrees with the transition of the Mexican economy toward trade opening, which is especially highlighted in the energy sector. With the aim to identify the causality and cointegration in those different stages, we define a broken trend by 1985, although other close dates are also suitable. Studies with alternative dates, such as between 1980 and 1986, yielded similar results. Tables 5 and 6 show the results on cointegration for both periods.

Table 5. Results of cointegration tests for the 1940-1985 period

\begin{tabular}{|l|c|c|c|c|}
\hline \multicolumn{5}{|c|}{ Engle-Granger cointegration results } \\
\hline Dependent & $\tau$-statistic & p-value & Z-statistic & $\begin{array}{c}\text { p- } \\
\text { value }\end{array}$ \\
\hline & \multicolumn{3}{|c|}{ Series: GDP, Electricity consumption } \\
\hline GDP & $-4.33 * *$ & 0.024 & $-49.32 * * *$ & 0.000 \\
\hline Electricity consumption & -2.45 & 0.565 & -9.22 & 0.668 \\
\hline & Series: GDP per capita, Electricity consumption \\
\hline GDP per capita & $-3.94 *$ & 0.056 & $-41.30 * * *$ & 0.000 \\
\hline Electricity consumption & -2.94 & 0.322 & -11.51 & 0.504 \\
\hline \multicolumn{5}{|c|}{ Johansen cointegration results } \\
\hline \multicolumn{7}{|c|}{ Eigenvalue } & Trace statistic & Critical Value & $\begin{array}{c}\text { p- } \\
\text { value }\end{array}$ \\
\hline & 0.297 & 22.43 & 20.26 & 0.024 \\
\hline None $* *$
\end{tabular}




\begin{tabular}{|l|c|c|c|c|}
\hline At most 1 & 0.154 & 7.22 & 9.16 & 0.115 \\
\hline & Series: GDP per capita, Electricity consumption \\
\hline None $* *$ & 0.351 & 19.38 & 15.49 & 0.012 \\
\hline At most 1 & 0.008 & 0.361 & 3.84 & 0.547 \\
\hline $\begin{array}{l}\text { Notes: estimates assume a constant and deterministic trend under the null hypothesis of } \\
\text { no cointegration. The superscripts } * * *, * *, \text { and } * \text { stand for rejection of the null }\end{array}$ \\
\hline \multicolumn{4}{|c|}{ hypothesis at the 1\%, 5\%, and 10\% levels of significance, respectively. } \\
\hline
\end{tabular}

Source: author's own estimates.

In this first stage, results on causality and cointegration are clearer. For example, in the first stage, both the Johansen and Engle-Granger tests agree that the series are cointegrated. The Johansen test indicates at least the existence of one cointegration relationship, while the Engle-Granger test highlights a cointegrating vector where electricity consumption explains changes in both GDP and GDP per capita, but not at the inverse. So, in the first stage the growth hypothesis prevails.

However, this relationship of causality and cointegration changed for the second period. Table 6 shows the results where causality is now bidirectional; according to the $\tau$-statistic the cointegrating vector is significant in both directions - that is, with GDP, GDP per capita, and electricity consumption as dependent variables, although for z-statistic there is not significant cointegration. In any case, the possible disagree between these two tests is a sign of the changing relationship occurring in the second period. On the other hand, the Johansen test rejects the null hypothesis for no cointegration relationship, but it accepts the null of at most one cointegration relationship.

Table 6. Results of cointegration tests for the $1985-2018$ period

\begin{tabular}{|l|c|c|c|c|}
\hline \multicolumn{5}{|c|}{ Engle-Granger cointegration results } \\
\hline Dependent & $\tau$-statistic & p-value & z-statistic & p-value \\
\hline & \multicolumn{4}{|c|}{ Series: GDP, Electricity consumption } \\
\hline GDP & $-2.96 * *$ & 0.039 & -8.13 & 0.217 \\
\hline Electricity consumption & $-2.94 * *$ & 0.040 & -8.11 & 0.218 \\
\hline & \multicolumn{5}{|c|}{ Series: GDP per capita, Electricity consumption } \\
\hline GDP per capita & $-3.04 * *$ & 0.032 & -9.60 & 0.148 \\
\hline Electricity consumption & $-3.03 * *$ & 0.033 & -9.56 & 0.149 \\
\hline & Johansen cointegration results \\
\hline \multicolumn{5}{|c|}{ Serigen: GDP, Electricity consumption } \\
\hline & \multicolumn{5}{|c|}{ Trace statistic } & Critical value & p-value \\
\hline None $* *$ & 0.355 & 21.17 & 20.26 & 0.037 \\
\hline At most 1 & 0.167 & 6.23 & 9.16 & 0.173 \\
\hline & Series: GDP per capita, Electricity consumption \\
\hline None $* *$ & 0.358 & 20.94 & 20.26 & 0.040 \\
\hline At most 1 & 0.157 & 5.83 & 9.16 & 0.204 \\
\hline
\end{tabular}

Notes: estimates assume a constant and deterministic trend under the null hypothesis of no cointegration. The superscripts $* *$ stands for rejection of the null hypothesis at the $5 \%$ level of significance.

Source: author's own estimates. 
It would be of interest to test the causality in each stage. Tables 7 and 8 report estimates of the VECM. They call attention to two main results. For the first stage, the variables show causality only in one direction. The GDP equation estimates a yearly adjustment of about $62 \%$ in the long run, while GDPpc equation averages an adjustment of $87 \%$. The negative value implies that the variations in the GDP are above its equilibrium value, and they need to be reduced in order to correct the disequilibrium. Moreover, a higher level of electricity consumption increases the level of GDP (and GDP per capita), but not at the inverse. Short run disequilibrium from the $\ln (\mathrm{EC})$ equation, on the other hand, is not significant, so the long run causality goes from the level of electricity consumption to the income level.

Table 7. Estimation results of the bivariate VECM for the period 1940-1985

\begin{tabular}{|c|c|c|}
\hline \multicolumn{3}{|c|}{ Equation of GDP and Electricity consumption (EC) } \\
\hline & \multicolumn{2}{|c|}{ Dependent variable } \\
\hline Regressors & $\Delta \ln (\mathrm{GDP})$ & $\Delta \ln (\mathrm{EC})$ \\
\hline $\mathrm{ECT}_{\mathrm{t}-1}$ & $-0.624 * * * \quad(-4.040)$ & $-0.391 \quad(-1.644)$ \\
\hline$\Delta \ln (\mathrm{GDP})_{\mathrm{t}-1}$ & $0.476 * * *(3.028)$ & $0.145 \quad(0.601)$ \\
\hline$\Delta \ln (\mathrm{EC})_{\mathrm{t}-1}$ & $-0.033 \quad(-0.2559)$ & $-0.095 \quad(-0.479)$ \\
\hline Constant & $0.031 *(1.893)$ & $0.081 * * * \quad(3.262)$ \\
\hline \multicolumn{3}{|c|}{$\begin{array}{c}E C T=\ln (G D P)-0.098 \ln (E C) \\
(-1.218)\end{array}$} \\
\hline \multicolumn{3}{|c|}{ Equation of GDP per capita (GDPpc) and Electricity consumption (EC) } \\
\hline Regressors & $\Delta \ln (\mathrm{GDPpc})$ & $\Delta \ln (\mathrm{EC})$ \\
\hline $\mathrm{ECT}_{\mathrm{t}-1}$ & $-0.871 * * * \quad(-4.846)$ & $-0.347 \quad(-1.136)$ \\
\hline$\Delta \ln (\mathrm{GDPpc})_{\mathrm{t}-1}$ & $0.439 * * * \quad(2.814)$ & $0.191 \quad(0.720)$ \\
\hline$\Delta \ln (\mathrm{EC})_{\mathrm{t}-1}$ & $-0.070 \quad(-0.622)$ & $-0.008 \quad(-0.043)$ \\
\hline Constant & $0.019 \quad(1.623)$ & $0.076 * * * \quad(3.835)$ \\
\hline \multicolumn{3}{|c|}{$\begin{array}{c}E C T=\ln (G D P p c)-0.054 \ln (E C) \\
(-4.824)\end{array}$} \\
\hline
\end{tabular}

Notes: Numbers in parentheses are t-statistics. The superscripts $* * *$ and $*$ stand for rejection of the null hypothesis at the $1 \%$ and $10 \%$ levels of significance, respectively. Estimates based on an optimal lag $=1$, according to the Schwarz criterion (BIC).

Source: author's own estimates.

In the second stage, bivariate relations notably change. Table 8 indicates that now a bidirectional causality seems to predominate; investigating the ECT coefficients shows that the disequilibrium corrections are statistically significant in both directions. However, the yearly adjustments estimated by the $\neg \ln (\mathrm{GDP})$ and $\square \ln (\mathrm{GDPpc})$ equations, which are around of $37 \%$ and $23 \%$ respectively, are almost half of the corresponding values for the first stage. Moreover, levels of electricity consumption and levels of income do not affect each other, as a result indicating that despite the observed causality between EC and income, now they have not the power to reinforce each other. This is important because it seems to suggest that electricity consumption and income are in a process of adaptation to the new scenario marked by the 
trade opening, where new rules and foreign competition can slow down their relationship and, thus, economic growth. Of course, this hypothesis requires more investigation.

Table 8. Estimation results of the bivariate VECM for the period 1985-2018

\begin{tabular}{|c|c|c|}
\hline \multicolumn{3}{|c|}{ Equation of GDP and Electricity consumption (EC) } \\
\hline & \multicolumn{2}{|c|}{ Dependent variable } \\
\hline Regressors & $\Delta \ln (\mathrm{GDP})$ & $\Delta \ln (\mathrm{EC})$ \\
\hline $\mathrm{ECT}_{\mathrm{t}-1}$ & $-0.371 * *(-2.511)$ & $-0.233 * * \quad(2.055)$ \\
\hline$\Delta \ln (\mathrm{GDP})_{\mathrm{t}-1}$ & $0.226(1.245)$ & $0.143 \quad(1.024)$ \\
\hline$\Delta \ln (\mathrm{EC})_{\mathrm{t}-1}$ & $-0.101 \quad(-0.491)$ & $0.150 \quad(0.955)$ \\
\hline Constant & $0.021 *(1.703)$ & $0.023 * * \quad(2.488)$ \\
\hline \multicolumn{3}{|c|}{$\begin{array}{c}E C T=\ln (G D P)+0.303 \ln (E C) \\
\end{array}$} \\
\hline \multicolumn{3}{|c|}{ Equation of GDP per capita (GDPpc) and Electricity consumption (EC) } \\
\hline Regressors & $\Delta \ln (\mathrm{GDPpc})$ & $\Delta \ln (\mathrm{EC})$ \\
\hline $\mathrm{ECT}_{\mathrm{t}-1}$ & $-0.370 * *(-2.456)$ & $-0.222 *(-1.915)$ \\
\hline$\Delta \ln (\mathrm{GDPpc})_{\mathrm{t}-1}$ & $0.211(1.160)$ & $0.128 \quad(0.915)$ \\
\hline$\Delta \ln (\mathrm{EC})_{\mathrm{t}-1}$ & $-0.104 \quad(-0.504)$ & $0.177 \quad(1.121)$ \\
\hline Constant & $0.008 \quad(0.731)$ & $0.025 * * * \quad(2.744)$ \\
\hline \multicolumn{3}{|c|}{$\begin{array}{r}E C T=\ln (G D P p c)+0.413 \ln (E C) \\
(2.590)\end{array}$} \\
\hline
\end{tabular}

Notes: Numbers in parentheses are t-statistics. The superscripts ***,**, and * stand for rejection of the null hypothesis at the $1 \%$ and $10 \%$ levels of significance, respectively. Estimates based on an optimal lag $=1$, according to the Schwarz criterion (BIC).

Source: author's own estimates.

\section{Concluding remarks}

Electricity consumption is a suitable indicator of the level of economic development a society has attained. Studying the stochastic behavior of electricity consumption, it is also possible to explain periods of high and low economic growth, such as the present study has demonstrated.

In Mexico, the causality goes from electricity consumption to GDP (and GDP per capita), indicating an energy-dependent economy. This finding allows the design of policies aimed at boosting investment in the energy sector, particularly in electricity generation. However, this direction of causality seems to have ended with the stage of trade opening experienced in the 1980s. Since then, the association strength notably diminished and the causality became bidirectional. It can be inferred from the results that now is the moment that Mexico needs to adopt a true energy policy, creating, for example, economic and regulatory instruments and energy taxes and subsidizing the several sources of renewable energies (e.g. solar, wind, etc.).

This study has also found that the statistical properties of electricity consumption, the GDP, the GDP per capita, and the GDP/EC ratio are stationary, but only after the presence of structural break has been taken into account in the model. This implies that in Mexico, electricity consumption has stimulated economic growth but in a changing relationship. Specifically, the stationarity of the GDP/EC ratio is 
indicative of the cointegration relationship between them. That is, the long run cointegration relationship has been broken, but after the structural break the gap recovers their equilibrium path in a new relationship where income is now less dependent on the electricity consumption. This means that in Mexico the growth hypothesis still predominates, although estimates suggest that this relationship is weakening in the most recent stage.

Mexico needs to improve the energy sector in order to recover the sustained growth of past stages. Changes provoked by the trade opening modified the relationship between electricity consumption and income per capita. The previous stage was characterized by increases in investment in electricity infrastructure and, as a result, income level greatly increased. However, with the trade opening the income level in the economy has diminished, besides reductions in electricity investment. Consequently, economic conditions are now in straits and Mexico needs to update its taxes policies, explore other sources of energy, such as renewable energy, and adopt technological innovation, with the end to overcome the relative backwardness of the energy sector.

The empirical evidence found in this study can be reinforced by examining this same phenomenon in other contexts, e.g. by investigating the behavior of electricity consumption at the level of the states in Mexico. The knowledge obtained from the states will help to understand the regional heterogeneity, the economic inequality, and the poverty. Furthermore, it will allow the design of more effective policies with regional perspectives in the energy sector.

\section{References}

[1] Abid, Mehdi (2016). "Energy Consumption-Informal Economic Growth Analysis: What Policy Options Do We Have?", Journal of the Knowledge Economy, 7: 207-218. https://doi.org/10.1007/s13132-014-0211-x

[2] Abid, Mehdi and Mraihi, Rafaa (2015). "Energy Consumption and Industrial Production: Evidence from Tunisia at both Aggregated and Disaggregated Levels", Journal of the Knowledge Economy, 6: 1123-1137. https://doi.org/10.1007/s13132-014-0190-y

[3] Arora, V. and Shi, S. (2016). "Energy Consumption and Economic Growth in the United States", Applied Economics, 48(39): 3763-3773. https://doi.org/10.1080/00036846.2016.1145347

[4] Asafu-Adjaye, J. (2000). "The Relationship between Energy Consumption, Energy Prices and Economic Growth: Time Series Evidence from Asian Developing Countries", Energy Economics, 22, 615-625. https://doi.org/10.1016/s0140-9883(00)00050-5

[5] Basu, S., Mousumi, R. and Pal, P. (2020). "Exploring the Impact of Economic Growth, Trade Openness and Urbanization with Evidence from a Large Developing Economy of India Towards a Sustainable and Practical Energy Policy", Clean Technologies and Environmental Policy, 22: 877-891. https://doi.org/10.1007/s10098-020-01828-9

[6] Bayraktutan, Y., Arslan, I., Özkan, G. S. and Çevik, F. S. (2012). "Industrial Sector Energy Consumption in Turkey-the Relationship between Economic Growth (1970-2010)", Journal of Economics and International Finance, 4(2): 30-35. https://doi.org/10.5897/jeif11.140

[7] Bertoldi, Paolo and Atanasiu, Bogdan (2011). "An In-Depth Analysis of the Electricity End-Use Consumption and Energy Efficiency Trends in the Tertiary Sector of the European Union", International Journal of Green Energy, 8(3): 306-331. https://doi.org/10.1080/15435075.2011.557843 
[8] Chang, Y. and Martinez-Chombo, E. (2003). "Electricity Demand Analysis Using Cointegration and ErrorCorrection Models with Time Varying Parameters: The Mexican Case”, Working Papers 2003-08, Rice University, Department of Economics.

[9] Dieck-Assad, F. A. and Peralta, E. (2013). "Energy and Capital Inputs: Cornerstones of Productivity Growth in Mexico: 1965-2004”, Empirical Economics, 44: 563-590. https://doi.org/10.1007/s00181-012-0557-5

[10] Erdogan, S., Akalin, G. and Oypan, O. (2020). "Are Shocks to Disaggregated Energy Consumption Transitory or Permanent in Turkey? New Evidence from Fourier Panel KPSS Test”, Energy, 197: Article 117174. https://doi.org/10.1016/j.energy.2020.117174Get

[11] Gómez, M. and Rodríguez, J. C. (2015). "Electricity Consumption and Economic Growth: The Case of Mexico", World Academy of Science, Engineering and Technology, Open Science Index 104, International Journal of Economics and Management Engineering, 9(8): 2803-2808. https://doi.org/10.5281/zenodo.1107974

[12] Gross, C. (2012). "Explaining the (non-) Causality between Energy and Economic Growth in the U.S. A Multivariate Sectoral Analysis", Energy Economics, 34: 489-499. https://doi.org/10.1016/j.eneco.2011.12.002

[13] Howarth, Richard B. (1997). "Energy Efficiency and Economic Growth", Contemporary Economic Policy, 15(1): $1-9$.

[14] Instituto Nacional de Estadística y Geografía (INEGI) (2008). Estadísticas históricas de México, Tomo II, Aguascalientes, INEGI.

[15] Islas-Samperio, J. M., Birlain-Escalante, M. O. and Grande-Acosta, G. K. (2020). "Toward a Low-Carbon Industrial Sector in Mexico", Energy Sources, Part B: Economics, Planning, and Policy. DOI: https://doi.org/10.1080/15567249.2020.1753855

[16] Joshua, U., Uzuner, G. and Bekun, F. V. (2020). "Revisiting the Causal Nexus between Coal Energy Consumption, Economic Growth, and Pollutant Emission: Sorting Out the Causality", Environmental Science and Pollution Research, 27: 30265-30274. https://doi.org/10.1007/s11356-020-09265-3

[17] Kablamaci, Baris (2017). "A Re-Examination of Causal Relation between Economic Growth and Energy Consumption: Evidence from 91 Countries”, Economics Bulletin, 37(2): 790-805.

[18] Lee, Chien-Chiang (2005). "Energy Consumption and GDP in Developing Countries: A Cointegrated Panel Analysis”, Energy Economics, 27: 415-427. https://doi.org/10.1016/j.eneco.2005.03.003

[19] Lumsdaine, R. L. and Papell, D. H. (1997). "Multiple Trend Breaks and the Unit-Root Hypothesis", Review of Economics and Statistics, 79: 212-218. https://doi.org/10.1162/003465397556791

[20] Massa, R. and Rosellón, J. (2020). "Linear and Nonlinear Granger Causality between Electricity Production and Economic Performance in Mexico", Energy Policy, 142: Article 111476. https://doi.org/10.1016/j.enpol.2020.111476

[21] Mighri, Z. and Ragoubi, H. (2020). "Electricity Consumption-Economic Growth Nexus: Evidence from ARDL Bound Testing Approach in the Tunisian Context", Global Business Review, forthcoming, https://doi.org/10.1177/0972150920925431

[22] Miketa, Asami and Mulder, Peter (2005). "Energy Productivity across Developed and Developing Countries in 10 Manufacturing Sectors: Patterns of Growth and Convergence", Energy Economics, 27: 429-453. https://doi.org/10.1016/j.eneco.2005.01.004

[23] Minh, N. and Ngoc, B. H. (2020). "Revisiting the Relationship between Energy Consumption and Economic Growth Nexus in Vietnam: New Evidence by Asymmetric ARDL Cointegration”, Applied Economic Letters, forthcoming, https://doi.org/10.1080/13504851.2020.1789543

[24] Moutinho, V., Madaleno, M. and Bento, J. P. (2020). "Cointegration and Causality: Considering Iberian Economic Activity Sectors to Test the Environmental Kuznets Curve Hypothesis", Environmental and Ecological Statistics, 27: 363-413. https://doi.org/10.1007/s10651-020-00449-1 
[25] Musah, M., Kong, Y., Mensah, I. A., Antwi, S. K. and Donkor, M. (2020). "The Link between Carbon Emissions, Renewable Energy Consumption, and Economic Growth: A Heterogeneous Panel Evidence from West Africa", Environmental Science and Pollution Research, 27: 28867-28889. https://doi.org/10.1007/s11356-020-08488-8

[26] Narayan, P. K. and Prasad, A. (2008). "Electricity Consumption-Real GDP Causality Nexus: Evidence from a Bootstrapped Causality Test for 30 OECD Countries", Energy Policy, 36(2): 910-918. https://doi.org/10.1016/j.enpol.2007.10.017

[27] Ng, S. and Perron, P. (2001). "Lag Length Selection and the Construction of Unit Root Tests with Good Size and Power", Econometrica, 69(6): 1519-1554. https://doi.org/10.1111/1468-0262.00256

[28] Omay, T., Hasanov, M. and Uçar, N. (2014). "Energy Consumption and Economic Growth: Evidence from Nonlinear Panel Cointegration and Causality Tests", Applied Econometrics, 34(2): 36-55.

[29] Ozcan, Burcu and Ozturk, Ilhan (2019). "Renewable Energy Consumption-Economic Growth Nexus in Emerging Countries: A Bootstrap Panel Causality Test", Renewable and Sustainable Energy Reviews, 104, 30-37. https://doi.org/10.1016/j.rser.2019.01.020

[30] Ozturk, Ilhan (2010). "A Literature Survey on Energy-Growth Nexus”, Energy Policy, 38(1): 340-349. https://doi.org/10.1016/j.enpol.2009.09.024

[31] Pegkas, P. (2020). "The Impact of Renewable and Non-Renewable Energy Consumption on Economic Growth: The Case of Greece", International Journal of Sustainable Energy, 39(4): 380-395. https://doi.org/10.1080/14786451.2019.1700261

[32] Perron, P. (1989). "The Great Crash, the Oil Price Shock, and the Unit Root Hypothesis", Econometrica, 57(6): 1361-1401. https://doi.org/10.2307/1913712

[33] Rodríguez Padilla, V. (2016). "The Electricity Industry in Mexico: Tension between the State and the Market”, Revista Problemas del Desarrollo, 47(185): 33-55. https://doi.org/10.1016/j.rpd.2015.11.001

[34] Saidi, Kais, Mbarek, M. B. and Amamri, M. (2018). "Causal Dynamics between Energy Consumption, ICT, FDI and Economic Growth: Case Study of 13 MENA Countries", Journal of the Knowledge Economy, 9: 228-238. https://doi.org/10.1007/s13132-015-0337-5

[35] Shahbaz, M., Tiwari, A. K. and Khan, S. (2016). "Is Energy Consumption per Capita Stationary? Evidence from First and Second Generation Panel Unit Root Tests", Economics Bulletin, 36(3): 1656-1669. https://doi.org/10.1007/s11300-012-0225-7

[36] Srinivasan, P. and Ravindra, I. S. (2015). "Causality among Energy Consumption, CO2 Emission, Economic Growth and Trade: A Case of India", Foreign Trade Review, 50(3): 168-189. https://doi.org/10.1177/0015732515589441

[37] Zerbo, Eléazar (2017). "Energy Consumption and Economic Growth in Sub-Saharan African Countries: Further Evidence", Economics Bulletin, 37(3): 1720-1744.

[38] Zivot, E. and Andrews, D. W. K. (1992). "Further Evidence on the Great Crash, the Oil-Price Shock, and the Unit-Root Hypothesis", Journal of Business and Economic Statistics, 10(3): 25-44. https://doi.org/10.2307/1391541 